\title{
Familieplanlegging i India
}

\author{
Nylig passerte jordens befolkning sju milliarder mennesker, og det er en utfordring å stabilisere verdens- \\ populasjonen på et bærekraftig nivå. I India bor det 1,198 milliarder mennesker, og hvert år fødes det \\ 26 millioner barn i landet.
}

\author{
Sigrid Halset \\ sigrid.halset@student.uib.no \\ Siren Morken \\ Det medisinsk-odontologiske fakultet \\ Universitetet i Bergen \\ Ingrid Miljeteig \\ Institutt for samfunnsmedisinske fag \\ Universitetet i Bergen \\ og \\ Forsknings- og utviklingsavdelingen \\ Helse Bergen
}

Den indiske staten har de siste tiårene satt søkelyset på kvinnelig sterilisering for å redusere befolkningen, med lite vekt på alternativ prevensjon og mannlig deltakelse. Myndighetene prøver nå å snu dette i den vedvarende kampen mot befolkningsveksten.

Gjennom kurset Global helse ved Universitetet i Bergen besøkte vi helseinstitusjoner i Sør-India. Her fikk vi et innblikk i dagens utfordringer ved familieplanlegging i India.

I 1950 var den totale fertilitetsraten i India 6,4 barn per kvinne, og i 2011 var den sunket til 2,6. Målet var imidlertid 2,1 barn per kvinne innen 2010, som er den raten man antar er nødvendig for at en befolkning skal holde seg stabil. Økonomisk vekst, utdanning av kvinner, bedre helsetilbud og målrettede prevensjonsprogrammer er blant de viktigste faktorene som har bidratt til nedgangen i fødselsraten (1).

Indiske myndigheter har siden det første familieplanleggingsprogrammet i 1952 iverksatt en rekke ulike tiltak med mål om å redusere befolkningsveksten (2). Fra slutten av 1960-årene intensiverte staten programmet og organiserte vasektomi-leirer, hvor det ble utført opptil 60000 inngrep per uke. Under unntakstilstanden 1975-77 lanserte Indira Gandhi (1917-84) et program som skulle være et «frontal attack on the problem of population», og som omfattet tvangssterilisering av menn med flere enn tre barn. I 1977 fikk landet ny statsminister, og i det nye programmet rettet man oppmerksomheten mot motivasjon, opplæring og frivillighet (3). I det nyeste familieplanleggingsprogrammet National Population
Policy legger man fortsatt vekt på informasjon og veiledning, slik at befolkningen skal være i stand til å gjøre frivillige og informerte valg (4).

Familieplanlegging ble anerkjent som en menneskerettighet i 1968 av FN (5). Ifølge WHOs årlige rapport, World Health Statistics 2011, er prevensjonsbruken blant fertile kvinner i India på $56 \%$ (6). Undersøkelser viser at ca. $20 \%$ av indiske kvinner ikke får oppfylt sine behov for familieplanlegging. Spesielt stort er problemet for dem som ønsker å få flere barn, men som vil ha lengre tid mellom hver fødsel og dermed trenger reversible prevensjonsmidler (7).

I undersøkelsen National Family Health Survey 3 (2005-06), utført av indiske myndigheter, ble kvinner i alderen 15-49 år intervjuet, og man fant at uønskede graviditeter og aborter er et stort problem (8). Av alle fødslene de fem siste årene før undersøkelsen var $11 \%$ av fødslene uønsket og $10 \%$ var ønsket til et annet tidspunkt. I aldersgruppen 30-49 år var nesten 30\% av alle fødsler uønsket. Fraværende helsetilbud, begrenset informasjon og manglende selvbestemmelse for mange kvinner er angitt som viktige forklaringer.

En studie viser at $16 \%$ av indiske menn mener at prevensjonsbruk hos kvinner er et tegn på promiskuitet (8). Med et svært variert utdanningsnivå i rurale områder har dessuten ikke kvinnene alltid forutsetninger for å forstå helseinformasjonen som blir gitt dem.

\section{Sterilisering - en enkel løsning?}

$\mathrm{Vi}$ besøkte et sykehus som regnes for å være et av Indias beste, hvor de lager sine egne familieplanleggingsprogrammer. Svært mange av kvinnene i distriktene rundt sykehuset blir fulgt opp i svangerskapet, og færre føder hjemme enn $i$ andre deler av India. Sykehuset tillater ikke selvbestemt abort. De tilbyr samlivskurs for nygifte par der paret får informasjon om prevensjonsmetoder og blir oppfordret til opphold mellom hvert svangerskap og sterilisering.

Postpartum tubektomi, som innebærer kirurgisk sterilisering innen 48 timer etter fødsel, blir tilbudt alle som har født sitt andre friske barn. Helsearbeiderne vi snak- ket med, understreket at steriliseringen bør skje rett etter fødselen. Om kvinnen blir utskrevet med en senere avtale, øker risikoen for at hun allerede er gravid igjen innen hun er tilbake.

Kvinnelig tubektomi er det vanligste prevensjonsmidlet i India, og hele seks millioner kvinner steriliseres årlig. Gjennomsnittsalderen er 25,5 år, og 77\% har aldri forsøkt annen prevensjon. Metoden er vanligst blant kvinner som har lav utdanning, flere enn tre barn og hos dem som allerede har født guttebarn (8).

Det gis økonomisk kompensasjon til den som steriliseres ved offentlige og godkjente private klinikker, og til helsepersonell som motiverer og informerer eller utfører selve inngrepet. I de såkalte høyfokusstatene med høyest fertilitetsrate får mannen 1100 rupi (ca. 130 norske kroner) for vasektomi, mens kvinner får 600 rupi (72 norske kroner) for tubektomi. Private leger som utfører sterilisering på offentlige klinikker, mottar også penger for hver utførte sterilisering - for å øke aktiviteten ved offentlige helseklinikker som har utstyr, men som mangler kvalifisert helsepersonell (9). Noe av kritikken mot pengeincentiver er at de kan tenkes å påvirke helsearbeidernes vurdering. Studier har også vist at noen av de fattigste har benyttet seg av dette som en inntekt, noe som forklares av at kompensasjonene er mye høyere enn gjennomsnittlig dagslønn i rurale strøk (10).

En studie viser at kvinner ikke nødvendigvis ville latt seg sterilisere om de hadde fått kjennskap til annen prevensjon. Opptil $85 \%$ av dem som ble motivert til sterilisering, fikk ikke tilstrekkelig informasjon om alternative prevensjonsmidler. I studien ble det gitt detaljert informasjon om ulike prevensjonsmidler, og resultatet ble at kun $17 \%$ av de informerte ville valgt sterilisering, mens $80 \%$ ønsket reversible metoder, som p-piller og spiral (11). Dette står i sterk kontrast til antall tubektomiinngrep som utføres hvert år i India.

\section{Tubektomi fremfor vasektomi?}

Undersøkelsen National Family Health Survey 3 viste at de fleste menn (78\%) mener at familieplanlegging ikke er kvinnens ansvar alene (8). Imidlertid utgjør 


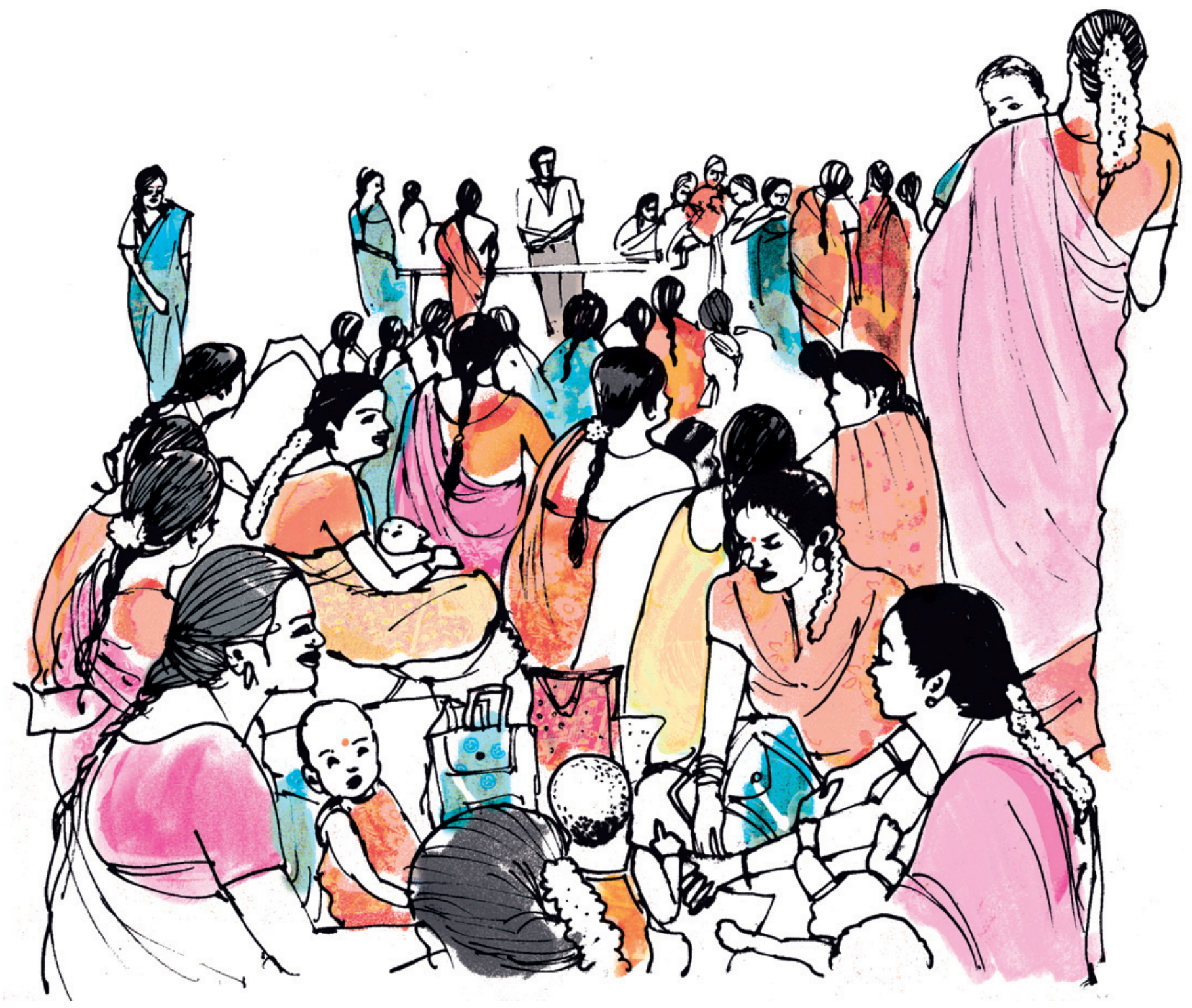

vasektomier bare ca. $1 \%$ av all prevensjonsbruk, mens tubektomier utgjør $66 \%$. Vasektomi er mindre invasivt, billigere og medfører færre komplikasjoner (7). Den lave andelen menn som steriliserer seg,

kan delvis forklares av manglende oppmerksomhet på mannens ansvar i kampanjene og negative ettervirkninger av den mannlige massesteriliseringen i 1970-årene. Forskjellen mellom kvinners og menns sosioøkonomiske status er også av betydning. Mannen er ofte familiens eneste inntektskilde, og tap av inntekt og frykt for komplikasjoner $\mathrm{i}$ forbindelse med inngrepet, gjør at få menn steriliseres (12). Samtidig har kvinner motivasjon og tradisjon for å ta kontroll over sin reproduktive skjebne.

I vårt møte med de unge familiene i India fikk vi et inntrykk av at verken mannen, mannens familie eller kona ønsket at mannen skulle sterilisere seg, da dette blir sett på som kvinnenes ansvarsområde. Legene vi snakket med, fortalte også om andre utbredte forestillinger som at steriliseringsinngrepet ville påvirke seksuallysten og medføre impotens. Ved sykehuset vi var på, oppfordret de sterkt til at mannen skulle delta i familierådgivning, og begge parter måtte skrive under steriliseringspapirene før inngrepet.

\section{Anestesi ved tubektomi}

På en mor-barn-avdeling ved et lokalt sykehus som vi besøkte, fikk pasientene en beroligende tablett før postpartum tubektomi, og det ble satt lokalanestesi i huden på magen. Legene forklarte at pasientene tidligere fikk morfin ved denne typen kirurgi, men at det på grunn av ressursmangel nå ikke ble gitt. Pasientene hadde det ofte svært smertefullt, men det ble som regel ikke gitt generell anestesi eller mer smertestillende. Legene forklarte at med det høye antallet tubektomier de gjennomførte hver dag, hadde de verken tid eller ressurser til å gi annen anestesi, i tillegg til at det ville utsette pasientene for større risiko enn å la være.

Ved å unngå generell anestesi sparer sykehuset tid og penger. Den indiske gynekologforeningen anbefaler kvinnelig sterilisering i lokalanestesi med premedikasjon (13). Også i den norske veilederen for generell gynekologi står det at sterilisering «kan utføres i lokalanestesi under tilrettelagte forhold» (14), men det er ikke vanlig å gjøre tubektomi verken 48 timer postpartum eller i lokalanestesi i Norge. I de amerikanske retningslinjene har man frarådet å bruke denne anestesimetoden, og myndighetene anbefaler epidural, spinal eller generell anestesi $(15,16)$.

\section{Konklusjon}

India har fortsatt en sterk befolkningsvekst, samtidig som mange ikke får dekket sitt prevensjonsbehov og blir uønsket gravide. Kvinnelig sterilisering har bidratt til å bremse befolkningsveksten i India og 
har for mange kvinner vært det eneste og kanskje beste alternativet for å begrense antall fødsler.

Det er nødvendig med bedre informasjon og tilbud om prevensjonsmetoder tilpasset hver enkelt, i tillegg til at man må stille krav til økt involvering av menn. Når flere kvinner i India nå får utdanning, vil man trolig se en endret bruk av prevensjonsmetoder.

\section{Sigrid Halset (f. 1988)}

er stud.med. ved Det medisinsk-odontologiske fakultet ved Universitetet i Bergen. Hun tok faget Global helse høsten 2009 i regi av Senter for internasjonal helse og Universitetet i Bergen. Forfatter har fylt ut ICMJE-skjemaet og oppgir ingen interessekonflikter.

\section{Siren Morken (f. 1987)}

er stud.med. ved Det medisinsk-odontologiske fakultet ved Universitetet i Bergen. Hun tok faget Global helse høsten 2009 i regi av Senter for internasjonal helse og Universitetet i Bergen. Forfatter har fylt ut ICMJE-skjemaet og oppgir ingen interessekonflikter.

\section{Ingrid Miljeteig (f. 1975)}

er lege og har ph.d.-graden i medisinsk etikk. Hun er postdok og forsker på kliniske prioriteringsbeslutninger og underviser i kurset Global helse ved Universitetet i Bergen.

Forfatter har fylt ut ICMJE-skjemaet og oppgir ingen interessekonflikter.

\section{Litteratur}

1. Lutz W, Kc S. Global human capital: integrating education and population. Science 2011; 333: 587-92.

2. Family planning fact sheets, India. WHO, South East Asia Region. www.who.int/mediacentre/ factsheets/fs351/en/index.html (16.3.2012).

3. Srinivasan K. Population policies and family plan ning programmes in India: a review and recommendations. Mumbai: International Institute for Population Sciences (IIPS). Newsletter 2006; 47: 6-44.

4. Santhaya KG. Changing family planning scenario in India 2004. Regional Health Forum, WHO SouthEast Asia Region 2004: 68-83.

5. United Nations Conference on Human Rights, Teheran, April 22 to May 13, 1968: Proclamation of Teheran. Am J Int Law 1969; 63: 674-7.

6. World Health Statistics 2011. Health service cover age. WHO, 2011. www.who.int/whosis/whostat/ EN WHS2011_Full.pdf (16.3.2012).

7. Report of the working group on population stabilization for the eleventh five year plan (2007-2012) New Delhi: Government of India, Planning Commission, 2012.

8. The National Family Health Survey 3 (NFHS 3), 2005-2006. Mumbai: International Institute for Population Sciences (IIPS). www.nfhsindia.org/ nfhs3.html (16.3.2012)

9. Annual Report 2010-2011. India: Ministry of Health and Family Welfare, 2011

10. Factors influencing the decision to undergo tubectomy in a rural area of Maharashtra state. Regional Health Forum, WHO, South-East Asia Region, 2003. www.searo.who.int/en/Section1243/ Section 1310/Section1343/Section1344/ Section1672_7148.htm (10.4.2012).

11. Baveja R, Buckshee K, Das K et al. Evaluating contraceptive choice through the method-mix approach. An Indian Council of Medical Research (ICMR) task force study. Contraception 2000; 61: 113-9.

12. Gender equality and women 's empowerment in India, The National Family Health Survey (NFSH3), 2005-2006: 126-29. India: Ministry of Health and Family Welfare. http: //pdf.usaid.gov/ ped docs/PNADQ633.pdf (16.3.2012).

13. Standards of female and male sterilization services. New Delhi: Government of India, The Federation of Obstetric and Gynaecological Societies of India (FOGSI), 2006.http://mohfw.nic.in/NRHM/
$\mathrm{RCH}$ /guidelines/Standard for female maler lization_services_final.pdf (16.3.2012).

14. Børdahl PE, Rygh A, Hannestad YS. Sterilisering. Veileder i generell gynekologi. Norsk gynekologisk forening, 2009 https://legeforeningen.no/Fagmed/ Norsk-gynekologisk forening/Veiledere/veileder-igenerell-gynekologi-2009/sterilisering/ (16.3.2012)

15. Bucklin BA, Smith CV. Postpartum tubal ligation: safety, timing, and other implications for anesthesia. Anesth Analg 1999; 89: 1269-74.

16. American Society of Anesthesiologists Task Force on Obstetric Anesthesia. Practice guidelines for obstetric anesthesia: an updated report by the American Society of Anesthesiologists Task Force on Obstetric Anesthesia. Anesthesiology 2007; 106 : 843-63.

Mottatt 26.9. 2011, første revisjon innsendt 18.1. 2012, godkjent 2.2. 2012. Medisinsk redaktør Trine B. Haugen 